\title{
SUSTAINABLE DEVELOPMENT GOALS AND GENERAL SKILLS INTEGRATED THROUGH GAMIFICATION IN HIGHER EDUCATION: A CASE STUDY
}

\author{
Ignacio Guillén Guillamón, Héctor Moreno Ramón, Marta Cabedo Fabrés, \\ Miguel Ferrando Bataller, Salvador Calvet Sanz, Sara Ibánez Asensio, Ana \\ Jiménez-Belenguer
}

Universitat Politècnica de València (SPAIN)

\begin{abstract}
In Spain, Universities began to participate in International Cooperation for Development (ICD) in the ' 90 s, mainly thanks to personal initiatives of university members. Nowadays ICD is a consolidated policy for higher education institutions. At this moment, Universities are committed with the "Sustainable Development Goals" (SDG) of the United Nations, which have constituted the core of the sustainable development agenda since 2015. SDG need to be considered from a multidisciplinary and integrated approach, especially in higher education. The accomplishment of the deal involves a change in the minds of lecturers and students, and innovative education strategies may help. Gamification is an important strategy to drive this change, due to the capabilities demonstrated to achieve deep learning and motivation improvement. The two-year innovation project applies gamification strategies to integrate SDG into the existing program with the aim of developing and evaluating "General Skills" (GS) in the Universitat Politècnica de València (UPV). The project is carried out by our innovation team GRIPAU (Interdisciplinary Group for University Learning).
\end{abstract}

On the first year of the project, the pilot case study was carried out over 51 students of Biotechnology and Building MSC. The results showed the gamification as a powerful tool to integrate SDG and general skills in Higher Education. One time the pilot case study was concluded, the methodology was adjusted and the experience was extended to the other subjects within the project.

The project second year plan includes applying the methodology to 255 students of 7 different subjects of Bachelor Degrees and MSC of Engineering, Architecture, Building Construction and Biotechnology, both in fall and spring terms.

The methodology consists of planning different activities through the term. First, a motivation and awareness activity is carried out to introduce the SDG through a general questionnaire about the origin and limits using a gamification tool such as Kahoot.

During the term, specific activities are developed with the aim of getting deeper knowledge about the SDG. The range of the activities is wide, from specific projects to debates. Finally, at the end of the term a final survey is conducted via gamification to get feedback on the level of awareness of the different issues addressed by the SDG and their guidelines.

The results obtained with the first data collection activity, showed $69 \%$ of correct answers while in the final surveys were $62 \%$. Similar results for the different scheduled data collection within the pilot case study with $76 \%$ and $60 \%$, respectively, although the total number of students in the final surveys was only 135 because some subjects are developed on the spring semester. The results on the secondyear project are equivalent, with less correct answers for the final test than for the initial one. About the subjective impressions of the activities, only $20 \%$ of the students gave feedback. All of them reported that the activities were very fun, learning effective and they would recommend the tool.

Keywords: Innovation, technology, research projects, SDG, General skills.

\section{INTRODUCTION}

\subsection{Sustainable Development Goals and Higher Education}

The Sustainable Development Goals (SDGs) of the United Nations (UN) aim to end poverty, protect the planet and ensure prosperity for everyone by 2030. The SDGs are on the agenda of most governments around the world and they encompass 17 life-changing goals with 169 specific 
objectives, to be developed within the next 10 years. Sustainability can guarantee the life and rights of people and planet earth and it is one of the fundamental pillars of SDGs, as well as Equity, that takes into account the reality of the most vulnerable and remote communities. SDGs also consider Universality, since the goals must be addressed globally, and the Commitment of all the countries of the world. Finally, the scope of the agenda should be highlighted, since it is really ambitious, and the goals are binding, as each country commits and sets its own particular national goals.

Regarding this new agenda and Higher Education, the university must work in the field of Sustainable Human Development, which implies training citizens committed to the world's problems, as well as generating capacities related to the SDGs among professors and education managers [1]. On the other hand, University is a key agent in building alliances that allow networking in various settings, as well as fostering its presence in international development cooperation networks. Another important aspect to highlight is the fact that Higher Education institutions should work on the SDGs in a comprehensive way, and not focus just on project management [2]. This approach must be done in an integrated, inclusive and multidisciplinary way, including the agenda in all university statutes and policies, and specifying specific measures in all areas, from training, provision of services or research, to the purchase of supplies or contracting.

Thus, it is clear that the University must be one of the main actors in integrating the 2030 agenda into society, and therefore, professors themselves are the ones who have to put it into practice in the classroom. For this, it is necessary to integrate the agenda crosswise across all University Degrees and Masters, and in turn, it must be considered that the changes are not brought by the knowledge itself, but by the people involved, which implies that training cannot be merely technical, but also in values.

This training should be stimulating and should be focused on imagining and creating sustainable ways of life [3]. Mere information on the agenda or on the dangers of less conscious life models will not suffice. Therefore, the inclusion of Transversal Competences (TC) and active methodologies is necessary to achieve this objective [4].

The Interdisciplinary Group for University Learning (GRIPAU) is a multidisciplinary team made up of professors who teach at different Universitat Politècnica de València (UPV) engineering schools and who have been working and evaluating transversal competences for years with the aim of promoting student excellence [5]. The different innovation projects carried out by the group, the gained experience in active methodologies and the knowledge of the transversal competences, together with the commitment of society and the UPV to the SDGs, are key factors for the development of the experience here described. In fact, some members of the team have already carried some previous successful experiences using gamification [6].

In this communication, we present the results of an innovation project based on applying gamification strategies to integrate SDG into the existing academic program of different courses. As it is explained next, gamification is a really appropriate tool to bring the SDGs closer to students, because of its many advantages.

\subsection{Gamification or M-Learning as a strategy in Higher Education}

Gamification, is known as the process of introducing elements and mechanisms of games into the classroom to motivate the students due to the intrinsic nature of the game itself. University professors who have used this methodology have reported that students gave very positive feedback [7]-[9]. Among the benefits, students highlighted the collaboration and the possibility of choice, the dynamism and interaction for the generation of ideas and the development of transversal competences. More specifically, in [10] after some learning experiences it was concluded that when gamification is used in the teaching-learning process following clear guidelines; it contributes to the academic success of students, increasing and consolidating their technical, social and behavioural competences and skills. Any M-learning platform is valid to achieve participation and interaction between the different actors in the learning process (app, web, RRSS ...) [11]. In this case we propose the use of the Kahoot! because it is an application widely known by both students and professors and it is easy and fast to use. Kahoot! use competition as a motivating factor [12]-[13]. Another advantage of Kahoot! is that it works perfectly on tablets and mobile phones both on the web and in a mobile application for both Android and iOS, allowing $100 \%$ of the students to participate [14]. 


\section{METHODOLOGY}

The experience was carried out in several engineering schools of the UPV, as well as in the Doctoral School. More specifically, the School of Agricultural Engineering and Environment - ETSIAMN participated with 186 students and 4 courses in the Degree in Agri-Food Engineering and Rural Environment, the Degree in Biotechnology and the University Master's Degree in Plant Health and Production and the Degree in Food Technology. The School of Telecommunications EngineeringETSIT participated with three courses and 190 students in the Master in Telecommunication Engineering and the Degree in Digital Technology and Multimedia, and the Schools of Building Engineering - ETSIE and Architecture ETSA participated with two courses and 24 Master Students. Finally, the Doctoral School participated with one course and 141 Students.

Table 1. Courses involved in the project

\begin{tabular}{|c|c|c|}
\hline Courses & Degree /Master /Doctorate & $\begin{array}{c}\text { Number of } \\
\text { students }\end{array}$ \\
\hline Recovery and restoration of degraded soils & $\begin{array}{c}\text { Degree in Agri-Food Engineering and } \\
\text { Rural Environment, }\end{array}$ & 17 \\
\hline Soil Technology Intensification & $\begin{array}{c}\text { University Master's Degree in Plant Health } \\
\text { and Production }\end{array}$ & 12 \\
\hline Industrial Microbiology & Degree in Biotechnology & 85 \\
\hline Public Health & Degree in Food Technology & 74 \\
\hline Workshop on Energy Efficiency \& Life Cycle & Master in Architecture & 16 \\
\hline Assessment & Master in Building & 8 \\
\hline Energy Efficiency & Master in Telecommunication Engineering & 56 \\
\hline Radio transmission systems and services & Master in Telecommunication Engineering & 56 \\
\hline Digital Society & Degree in Digital Technology and & 78 \\
\hline Researchers' Career & Moltimedia & 141 \\
\hline
\end{tabular}

The development of this experience was developed in Kahoot! an online platform that has become a tool to be applied in learning sessions due to its agility and ease of use by students who are familiar with mobile applications in their daily life. As explained before, Kahoot! has been used in several university experiences in which the researchers have highlighted the increased motivation of students in the course, as well as its potential to promote and reinforce meaningful student learning [15]-[16].

As observed in Fig. 1, the development of the experience was carried out based on three combined actions during the teaching semester.

The first action included evaluation through M-learning (Kahoot!) on the 2030 agenda and the SDGs. For that purpose, two tests (initial and final) were developed in Kahoot! A series of questions related to the SDGs and the 2030 agenda were established at two levels. The first survey was carried out to find out what the students knew about both concepts, without having exposed anything by teaching staff. We wanted to know the previous knowledge of students about the SDGs and the 2030 agenda. On the contrary, the final test raised deeper questions and took place after a classroom-based session where professors explained the SDGs and the 2030 agenda.

The second action was to develop a class exposition on SDGs, highlighting their meaning and implications. This action was performed after the initial test of Kahoot!

The last action and most important was to develop a technical project or case study where the students have to reflect on one or several SDGs according to the concrete activity, the syllabus or specific topics of each course. The project or case study provided students with the possibility of applying the technical knowledge learnt in the course to a realistic problem related to the objectives of the 2030 agenda. Complementary, the case study was used to integrate the practice and evaluation of different transversal competences, such us communication skills, critical thinking, problem solving, 
planning, or ethical responsibility. In some of the courses participating in the experience, the case study was replaced by a debate on a current topic related to the 2030 agenda. Likewise, these debates were also used to evaluate transverse skills, like team working, innovative thinking or oral communication.

To sum up, the proposed methodology is based on two main pillars. One is the evaluation of the knowledge of the SDGs through gamification in two stages of the learning process and the other is based on the student's personal work of the SDGs and the 2030 agenda during the course developing a case study or preparing and participating in a debate.

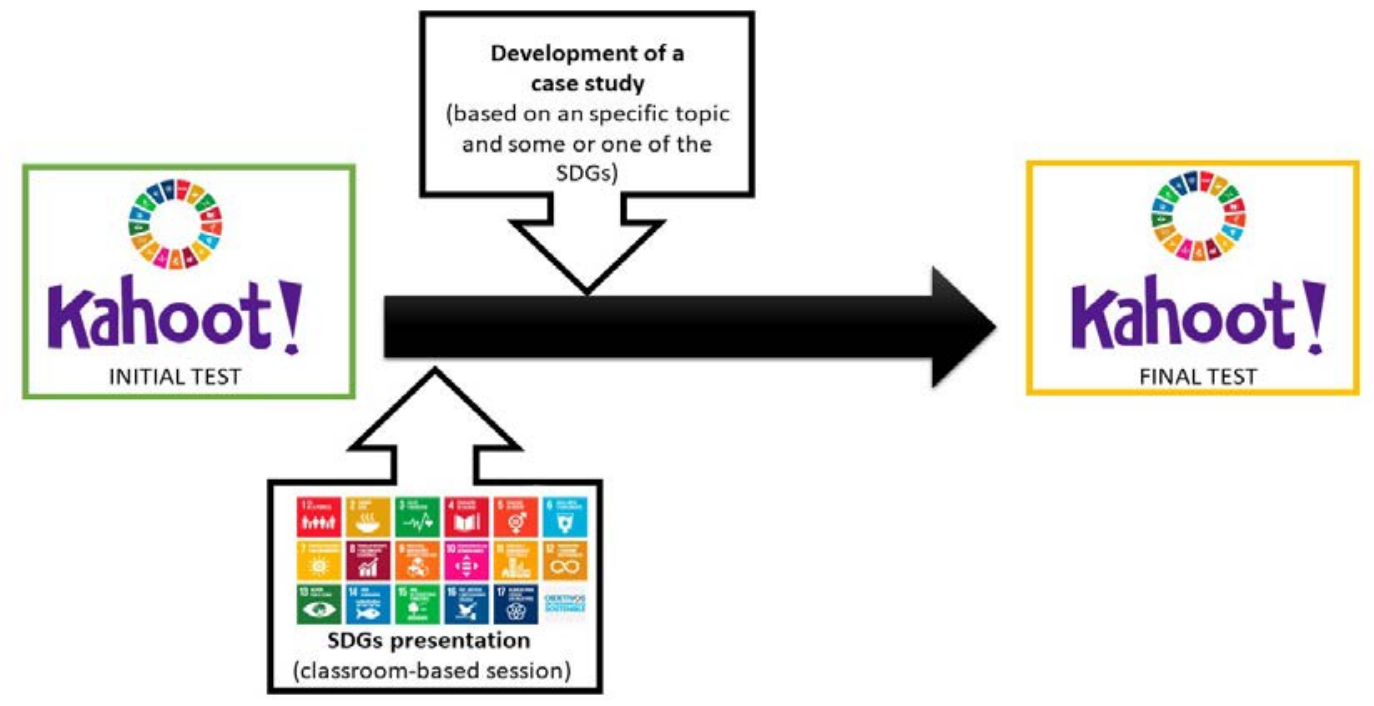

Figure 1. Timeline of the experience with the actions carried out

The treatment of the data generated by Kahoot! has only been based on a statistical summary of the data set. The target population has been UPV students without distinction of learning levels.

\section{RESULTS}

The results obtained from the experiences comprise the answers of 255 students. The distribution of topic areas of the students was: $70 \%$ biotechnology \& agronomical engineering, $20 \%$ telecommunication engineering and $10 \%$ architecture \& construction engineering. More specifically, gamification methodology was applied for activities 1 and 4 of a defined working plan. The first activity was a questionnaire that consisted of 9 questions and was focused on the first time the students heard of SDG. Results for all samples are shown in Table 2.

In the initial survey, results showed $69,18 \%$ of correct answers in the questionnaire. This result revealed that students had a high knowledge of SDGs, as students were aware of their meaning, origin and social implications. In the feedback gained from the experience, for the question "How much fun was it?" the score was 5 out of 5 , which shows that the activity was highly inspiring due to the entertainment it produced.

Table 2. Results for Activity 1: Initial Kahoot!

\begin{tabular}{lccc}
\hline \multicolumn{1}{c}{ Overall Performance } & & \\
\hline Total SDG knowledge (\%) & & $69.18 \%$ & $30.82 \%$ \\
\hline Feedback (19.22\% answered) & & & \\
\hline How fun was it? (out of 5) & & 5 & \\
\hline Did you learn something? & $100 \%$ Yes & $0 \%$ No & \\
\hline Do you recommend it? & $100 \%$ Yes & $\%$ No & \\
\hline How do you feel? & $\begin{array}{c}100 \% \\
\text { Positive }\end{array}$ & $\begin{array}{c}0 \% \\
\text { Neutral }\end{array}$ & $\begin{array}{c}0 \% \\
\text { Negative }\end{array}$ \\
\hline
\end{tabular}


Only a $19.22 \%$ of the students surveyed gave feedback, and stated that they had acquired new knowledge about SDG and that they would highly recommend this activity. Their attitude was always positive.

After this first survey trough gamification, the SDG were introduced to the students through complementary material obtained from UN website. Afterwards, we developed specific activities in order to work the SDG together with the transversal competences of each course. In Industrial Microbiology course a debate about biopiracy and the destruction of ecosystems was conducted and in the case of Energy Efficiency in Building course a performance-based contest about NZEB (Nearly Zero Energy Building) house project was carried out. Both experiences were very well received by the students.

Students had time to explore by themselves the UN website when all specific activities were completed Afterwards, we performed the final survey corresponding to activity 4 . The students of biotechnology \& agronomical engineering and the students of architecture \& construction engineering completed the final survey. The total number of students involved was 95 with an asymmetrical distribution with $72,63 \%$ students of biotech \& agronomical engineering and the rest of architecture \& construction engineering.

Final questionnaire was composed of 16 questions that focused on SDGs related to the contents of each specific course. Results are summarized in Table 3.

Table 3. Results for Activity 4: Final Kahoot!

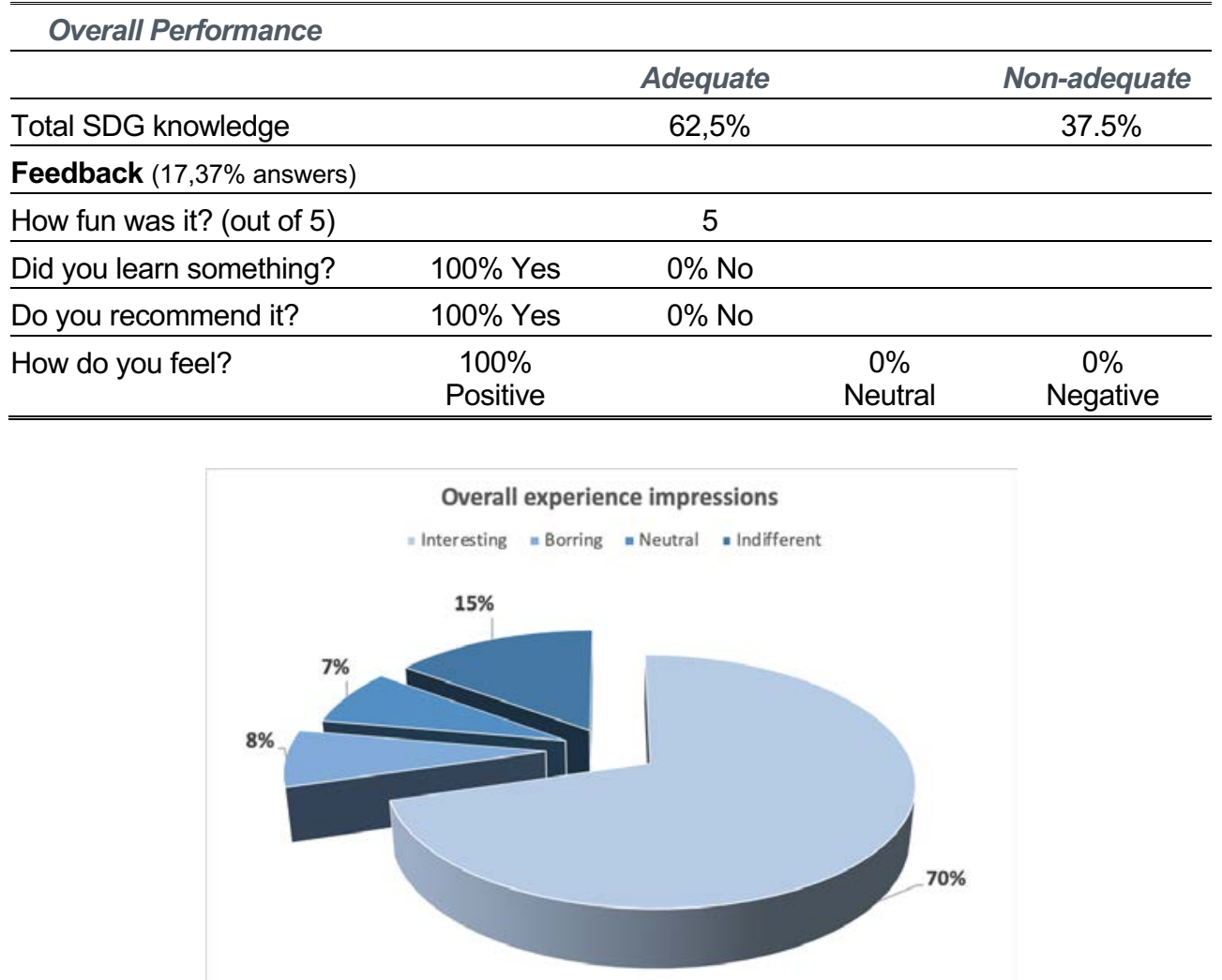

Figure 2. Results for overall impressions obtained from Kahoot!

In the final survey, correct answers shown a slowly decreasing to $62.5 \%$. The overall feedback for the activity was similar. A $17,37 \%$ of the students participating provided answers through the Kahoot! feedback with positive feelings, learning benefits and a high degree of recommendation for others topics.

Regarding their overall impressions about all the activities, as can observed in Fig.2, for $70,37 \%$ of the students the activities were interesting, for $7,41 \%$ they were bored and for up to $22,22 \%$ the activities 
were neutral or indifferent. Therefore, it can be extracted that most part of the students liked the activities carried out and that in general, they are receptive to this king of learning experiences.

The results obtained on the survey campaign performed in the academic year 2019-2020 were similar to the ones recorded in 2018-2019 [6]. In general, the feedback about the overall experience was positive. A slight decrease of correct answers was observed for the final survey when compared with the initial one. Probably, this decrease is due to the different difficulty level of the questions included in the initial and the final survey. The gap in the difficulty level of the questions should be overcome through the student's personal work. However, in some cases it didn't happen because of the not obligatory nature of some of the activities proposed to develop the transverse competences and to learn about the SDGs.

Complementary to the surveys, feedback from Telecom students was obtained throughout personal assessment included in the case study analysis they performed. Students valued the experience very positively, highlighting that they have realized that it is possible to contribute to the SDGs and 2030 agenda from their professional practice.

\section{CONCLUSIONS}

The playful participation of the students allowed them to be introduced to the SDGs that in many cases were unknown to them, regardless of the level of studies. Gamification combined with other activities, such as case studies or debates, has revealed as an effective technique to integrate the 2030 agenda crosswise across different Bachelor's Degrees and Masters.

The general feedback of the students on the Kahoot! tests was very positive, and most part of them agreed that they would highly recommend this activity to others.

Remarkably, the responses of students to the final test were slightly worse than for the initial one. We assume that final questions about SDGs could be more difficult, and the test was conducted after students had focused on a few SDGs, while the final surveys focused over all the SDGs. This should make us rethink the level of questions in the final survey and focus the questions on the SDGs that have been worked on each course.

The proposed activities based on debates, technical projects or realistic case studies related to SDGs can contribute to create a sense of global citizenship on the students and intercultural understanding.

Future work will focus on which SDGs could be worked on in more depth for each thematic area and degree, and if that approach could increase the degree of student involvement with respect to the SDGs.

\section{ACKNOWLEDGEMENTS}

The authors gratefully acknowledge the financial support from the Universitat Politècnica de València, Convocatoria Docencia + Aprendizaje $2018(A+D)$ PROYECTO DE INNOVACIÓN Y MEJORA EDUCATIVA (PIME).

\section{REFERENCES}

[1] J. Sureda, F. Sánchez, J. Benayas, "Sostenibilidad de las universidades y objetivos de desarrollo sostenible de Naciones Unidas," EI Blog de Studia XXI. Universídad. Una conversación pública sobre la Universidad. Retrieved from: http://www.universidadsi.es/sostenibilidad-lasuniversidades-objetivos-desarrollo-sostenible-naciones-unidas/

[2] Resumen de los Diálogos sobre Universidad y Desarrollo Sostenible. Observatorio de la Cooperación Universitaria al Desarrollo (OCUD). Jornadas OCUD 2016. Retrieved from: http://www.ocud.es/es/pl59/actividades-propias-y-en-red/jornadas-ocud/id2086/resumen-de-losdialogos-sobre-universidad-y-desarrollo-sostenible.htm

[3] P. Munuera, E. Navarro, "Innovación en la Evaluación de Competencias Transversales. El instrumento PIAESCE," Biblioteca Digital Repositorio Académico, Universidad del Zulia, año 31, n.1, pp. 510-528, 2015. 
[4] C. Mezarina, H. Páez, O. Terán, R. Toscano, "Aplicación de las TIC en educación superior como estrategia innovadora para el desarrollo de competencias digitales". Revista científica de tecnología educativa, n.1, pp. 88-101, 2014.

[5] H. Moreno, S. Ibáñez, A.I. Jiménez, A. Martínez, S. Calvet, M. Ferrando I. Guillén, M. Cabedo, "A multidisciplinary approach for the assessment of generic skills through ICTS 3.0," 10th International Conference of Education, Research and Innovation, ICERI2017 Proceedings, pp. 5239-5244, 2017.

[6] A. Jiménez, S. Calvet, H. Moreno, S. Ibáñez, M. Cabedo, M. Ferrando, A. Martínez, I. Guillem, "Integration of SDG and general skills through gamification," 12th International Conference of Education, Research and Innovation, ICERI 2019 Proceedings, pp.10600-10604, 2019.

[7] A. Sánchez-Mena, J. Martí-Parreño, "Gamification in Higher Education: Teachers' Drivers and Barriers," International Conference, The Future of Education, 2015. Retrieved from: https://conference.pixel-online.net/FOE/files/foe/ed0006/FP/2937-ENT1883-FP-FOE6.pdf

[8] Derya Orhan Göksün, Gülden Gürsoy. "Comparing success and engagement in gamified learning experiences via Kahoot and Quizizz." Computers \& Education 135, pp. 15-29, 2019.

[9] H. Bicen, S. Kocakoyun, "Perceptions of students for gamification approach: Kahoot as a case study," International Journal of Emerging Technologies in Learning (iJET 2018) 13.02, pp.72-93, 2018.

[10] M. J. Ferreira, F. Moreira, D. Fonseca, "Gamification in higher education: the learning perspective," Experiences and perceptions of pedagogical practices with Game-Based Learning \& Gamification. Braga, Portugal Research Centre on Education (CIEd), Institute of Education, University of Minho, pp. 195-218, 2019.

[11] H. Bicen, S. Kocakoyun, "Determination of University Students' Most Preferred Mobile Application for Gamification," World Journal on Educational Technology, current issues v9, n.1, pp. 18-23, 2017.

[12] I. Varannai, P. Sasvari, A. Urbanovics. "The Use of Gamification in Higher Education: An Empirical Study," International Journal of Advanced Computer Science an Applications. 2017 n.8, iss.1, 2017.

[13] G. Martínez-Navarro "Tecnologías y nuevas tendencias en educación: aprender jugando. El caso de Kahoot." Opción: Revista de Ciencias Humanas y Sociales, n. 83, 252-277, 2017.

[14] L. Rodríguez-Fernández,"Smartphones y aprendizaje: el uso de Kahoot en el aula universitaria," Revista Mediterránea de Comunicación/Mediterranean Journal of Communication 8.1, pp.181189, 2018.

[15] P.A. Baszuk, M.L. Health. "Using Kahoot! to increase exam scores and engagement," Journal of Education for Business, pp. 1-5, 2020.

[16] D. Tan, M. Ganapathy, M. Kaur. "Kahoot! It: Gamification in Higher Education,", Pertanika J. Soc. Sci. \& Hum. 26 (1): 565 - 582, 2018. 